Article

\title{
Sugar Content in Processed Foods in Spain and a Comparison of Mandatory Nutrition Labelling and Laboratory Values
}

\author{
María José Yusta-Boyo ${ }^{1, *}$, Laura M. Bermejo ${ }^{2,3}$, Marta García-Solano ${ }^{1}$, \\ Ana M. López-Sobaler 2,3 (D), Rosa M. Ortega 2,3 (D), Marta García-Pérez ${ }^{1}$, \\ María Ángeles Dal-Re Saavedra ${ }^{1}$ and on behalf of the SUCOPROFS Study Researchers ${ }^{\dagger}$ \\ 1 Spanish Food Safety and Nutrition Agency, Alcala, 56., 28014 Madrid, Spain; mgarcias@mscbs.es (M.G.-S.); \\ mgarciape@mscbs.es (M.G.-P.); mdalre@mscbs.es (M.Á.D.-R.S.) \\ 2 Nutrition and Food Science Department, Faculty of Pharmacy, Complutense University of Madrid, \\ 28040 Madrid, Spain; mlbermej@ucm.es (L.M.B.); asobaler@ucm.es (A.M.L.-S.); rortega@ucm.es (R.M.O.) \\ 3 VALORNUT Research Group, Faculty of Pharmacy, Complutense University of Madrid, 28040 Madrid, Spain \\ * Correspondence: mjyusta@mscbs.es; Tel.: +34-913380062 \\ + For more information see Acknowledgments Section.
}

Received: 21 February 2020; Accepted: 10 April 2020; Published: 13 April 2020

check for updates

\begin{abstract}
To reduce the sugar content of processed foods through reformulation, the first step is to determine the content of the largest sources of sugars in each country's diet. The aim of this work was to describe the sugar content in the most commonly consumed processed foods in Spain and to compare that sugar's labelling and laboratory analysis values (LVs and AVs, respectively) to confirm its adequacy. A sample of the 1173 most commonly consumed processed foods in Spain (28 groups; 77 subcategories) was collected. For each product, the total sugar content was compared according to its $\mathrm{AV}$ and LV. The median (25th -75 th percentiles, interquartile range) sugar content by group was calculated for the total sample, and the groups were classified as "high sugar content" when this value was above $22.5 \mathrm{~g} / 100 \mathrm{~g}$ of product. The adequacy of the $\mathrm{LV}$, according to the European Union (EU) tolerance requirements, was then evaluated, and each subcategory median was compared with the AV to determine its appropriateness via a median test for independent samples $(p<0.05)$. In total, 10 out of 28 groups presented high sugar content. Moreover, $98.4 \%$ of the products met the EU tolerance ranges. Finally, only one subcategory ("cured ham") presented significant differences between the AV and LV median values $(0.4 \mathrm{~g}$ vs. $0.1 \mathrm{~g}$ sugar $/ 100 \mathrm{~g}, p<0.05)$. The groups of food products whose sugar content reduction could have the greatest impact on public health were identified. In addition, our study showed the high adequacy of LV with the EU labeling tolerance requirements, as well as the LV's appropriateness as a tool to implement actions aimed at reducing sugar consumption.
\end{abstract}

Keywords: nutrition labeling; food labeling; food processing; nutrition policy; Spain; food analysis; dietary sugars; reformulation

\section{Introduction}

The prevalence of overweight, obesity, and related non-communicable diseases (cardiovascular diseases, diabetes, and cancer) remains high in all European countries, including Spain [1].

The impact of dietary risk factors on the mortality and morbidity associated with non-communicable diseases highlights the importance of implementing measures to improve the quality of citizens' diets within national health policies [2]. 
Diets must meet energy needs and provide a variety of foods of a high nutritional quality that are safe to consume. Moreover, these diets should be sustainable, affordable, accessible, and culturally acceptable [3].

The European Union (EU) has long promoted initiatives to tackle obesity and to improve nutrition in European countries. One of the main initiatives of the European Commission was the adoption of the White Paper of 30 May 2007 entitled 'A Strategy for Europe on Nutrition, Overweight and Obesity related health issues' [4], focusing on actions that can be taken at the local, regional, national, and European levels. One of the initiatives included in this document is for the food industry (including retailers) to reformulate its products, particularly by reducing the content of salt, sugar, and fats.

In this regard, the High Level Group on Nutrition and Physical Activity (HLGNPA), composed of representatives of EU Member States and the European Commission, launched two EU Frameworks for the reformulation of food products: the EU Framework for National Initiatives on salt reductions [5] and the EU Framework for National Initiatives on Selected Nutrients [6] with two annexes: Annex I on saturated fats [7] and Annex II on added sugars [8]. These EU frameworks and annexes establish benchmarks and timelines for nutrient content reduction, focusing their action on certain food categories while taking into account the priorities, health needs, baseline nutrient contents, traditions, and pattern of consumption of each member state.

For more than a decade, the Ministry of Health in Spain, through the NAOS Strategy (Strategy for Nutrition, Physical Activity and the Prevention of Obesity) of the Spanish Agency for Food Safety and Nutrition (Spanish acronym AESAN, formerly Spanish Agency for Consumption, Food Safety and Nutrition, AECOSAN) has promoted reformulation initiatives for food and beverages, following the recommendations outlined in the HLGNPA Frameworks. To establish these initiatives, different studies have been carried out to determine the nutrient consumption and main food sources of the population and to ascertain the nutrient content (mainly fats and salt) of processed products [9-13]. The results of these studies have facilitated measures to reduce fats and salt in the main processed foods in Spain. Among these initiatives are the agreements between AESAN and food sector associations to achieve nutrient reduction targets, which were committed to all companies that belong to the sector association [14]. A successful example of public-private collaboration to achieve the reduction of salt content is the agreement (legal document) between AECOSAN, the Spanish Confederation of Bakers (CEOPAN by its Spanish acronym), and the Spanish Association of Manufacturers of Frozen Dough (ASEMAC by its Spanish acronym) signed in 2004, in which a salt reduction from $22 \mathrm{~g} \mathrm{NaCl} / \mathrm{Kg}$ in bread flour in 2004 to a maximum of $18 \mathrm{~g} \mathrm{NaCl} / \mathrm{kg}$ by 2008 was agreed upon. The average $\mathrm{NaCl}$ content measured in 2008 was $16.3 \mathrm{~g}$ of $\mathrm{NaCl} / \mathrm{Kg}$ in bread-making flour [14]. In addition, a new study conducted in 2014 concluded that the salt content in bread in Spain has remained stable since 2008 [15].

However, no study has yet been conducted to ascertain the sugar content in processed products in Spain in order to establish reference values for addressing public health food policies, such as the reformulation or improvement of processed food and beverage composition.

For this reason, at the end of 2016, AESAN conducted the present study to describe the sugar content in the food groups included in the Annex II of added sugar [8] and in the most commonly consumed processed foods in Spain, especially by children and adolescents [16]. In addition, the other secondary objectives were to compare the label value (LV) with the laboratory analysis value (AV) in order to assess the adequacy of the LV based on the EU labelling requirements, and to study the appropriateness of using the label values as reference data to monitor the reformulation of sugar and other nutrients or for strategies such as front-of-pack labelling or marketing restrictions.

\section{Materials and Methods}

\subsection{Sample Selection}

We selected 28 food and beverage groups of processed foods to perform the present study (Table 1), starting with the 11 groups recommended in the Annex II (on added sugar) in the HLGNPA [8]. Some 
of these 11 groups were divided due to the diversity of products included in each of them. For example, "Sugary dairy products and other similar products" was divided into six groups: flavoured milk drinks, drinking yoghurt, yoghurt, dairy-based desserts, cheeses, and soy drinks. Moreover, according to the results observed in the ENALIA study (National Dietary Survey on the Child and Adolescent Population), the groups "milk", "juices", "nectars", and "meat products" were included because these groups represent an important source of energy for children and adolescents in Spain [16].

Table 1. Selected food and beverage groups for this study.

\begin{tabular}{|c|c|}
\hline $\begin{array}{c}\text { Food Groups to Focus Action on Added Sugar } \\
\text { Reduction, According to Annex II of the High } \\
\text { Level Group on Nutrition and Physical Activity } \\
\text { (HLGNPA) }\end{array}$ & $\begin{array}{l}\text { Selected Groups for this Study } \\
\text { (HLGNPA Groups + other Highly Consumed } \\
\text { Groups by Spanish Children) }\end{array}$ \\
\hline Sugar sweetened Beverages & Sugar sweetened beverages \\
\hline \multirow{6}{*}{ Sugar sweetened dairy and dairy imitates } & Flavoured milk drinks \\
\hline & Drinking yoghurt \\
\hline & Yoghurt \\
\hline & Dairy-based desserts \\
\hline & Cheese \\
\hline & Soy drinks \\
\hline Breakfast cereals & Breakfast cereals and cereal bars \\
\hline Bread and bread products & Special packaged bread \\
\hline \multirow{2}{*}{ Bakery products (e.g., cakes and cookies) } & Baking and pastries \\
\hline & Biscuits \\
\hline \multirow{3}{*}{ Confectionaries } & Sweets \\
\hline & Chocolates \\
\hline & Other sweets (chewing gum, marshmallow, etc.) \\
\hline $\begin{array}{l}\text { Ready meals (including ready to prepare products } \\
\text { like dry soups, dried mashed potatoes, rice mixture) }\end{array}$ & Ready meals \\
\hline \multirow{2}{*}{ Savoury snacks } & Savoury snacks \\
\hline & Crisps \\
\hline Sauces (including ketchup) & Sauces \\
\hline \multirow{4}{*}{ Sugar sweetened desserts, ice cream and topping } & Desserts \\
\hline & Ice creams \\
\hline & Jam \\
\hline & Confitures \\
\hline \multirow{6}{*}{ Canned fruits and vegetables } & Canned pineapple \\
\hline & Other Fruits in syrup \\
\hline & Milk \\
\hline & Fruit juices \\
\hline & Nectars \\
\hline & Meat products \\
\hline
\end{tabular}

The 28 processed food groups selected were classified into 77 subcategories according to their composition and legal denomination. For some analyses, classification by subcategory was used; this type of classification is considered more appropriate than classification by group due to the 
variability within a group. The number of products to be analyzed in each food subcategory was established by consensus among researchers. Food products were selected from among those with the greatest presence in the national market at that time (including both brand names and retailer brands), according to data published in the report on the Alimarket study in 2015 [17]. This report provided the most important economic and financial variables by sector in Spain, including information about 9286 companies in the food sector.

\subsection{Data Collection}

Once the groups and subcategories to be studied were selected, the total number of processed product samples was 1173 . The study was awarded through public tender to "AENOR Laboratorio Alimentacion" (AENOR Food laboratory), which carried out the plans to purchase the products. All samples were acquired in October 2016 and transported under adequate storage conditions to "AENOR Laboratorio Alimentacion" to proceed with the storage and subsequent determination of the total sugar AV of each processed product. In addition, the total sugar LV declared in the mandatory nutrition labelling (MNL) was recorded.

The Luff-Schoorl method was used to measure the total sugar AV. This method is the official method to control sugars intended for human consumption in Spain [18] according to the European legislation First Commission Directive of 26 July 1979, which outlines the community methods for testing certain sugars intended for human consumption (79/786/EEC) [19]. This method involves the elimination of all reducing materials other than sugars present in the sample by drying; subsequently, the sugar content is assessed based on the reducing action in a cupro-alkaline solution.

In order to collect the total sugar LV, we considered the proposed methodology for the monitoring and food reformulation initiatives of the Joint Action on Nutrition and Physical Activity (JANPA) of the European Commission [20]. In this methodology, the MNL was accepted as the data source to collect nutritional information.

\subsection{Statistical Analysis}

The data collected were recorded in a database designed ad hoc (for this study). This procedure was carried out in other countries as a tool for the reformulation and monitoring of processed food and beverage composition (Oqali database) [21]. Statistical analyses were performed using the SPSS software (SPSS, version 25.0; SPSS, Chicago, IL, USA).

For a descriptive study of the total sugar AV and LV, the median (25th-75th percentiles, interquartile range) were calculated for each food group, in the total sample $(n=1173)$, and in the two subsamples, according to the presence of nutrition claims about sugar content (light, low sugar content, no added or zero sugar, etc.) on the label $(n=64)$ vs. the absence of a sugar-based nutritional claim $(n=1109)$. Moreover, an adequacy study of the LV based on the EU labelling requirements, using the tolerance of the values declared on the labelling [22], was conducted. The final sample used to study adequacy of the LV included 1074 products (excluding products with nutritional claims and without a LV). A product met the tolerance range ("Meets") when its $\mathrm{LV}<10 \mathrm{~g} / 100 \mathrm{~g}$ of product and its deviation from the AV was $\pm 2 \mathrm{~g}$; when its LV was $10-40 \mathrm{~g} / 100 \mathrm{~g}$ and its deviation from the AV was $\pm 20 \%$; or when its $\mathrm{LV}>40 \mathrm{~g} / 100 \mathrm{~g}$ and deviation from the AV was $\pm 8 \mathrm{~g}$. Any product outside of these tolerance ranges was classified as "Does not meet".

Finally, an appropriateness study of LV as reference data for reformulation, monitoring, and other strategies was conducted. For the sample consisting of 1074 products, the LV and AV medians of each product subcategory were compared using the SPSS Median Test for 2 Independent Medians $(p<0.05)$.

\section{Results}

A flowchart with the sample selection and the different analyses carried out in the present study is detailed in Figure 1. 


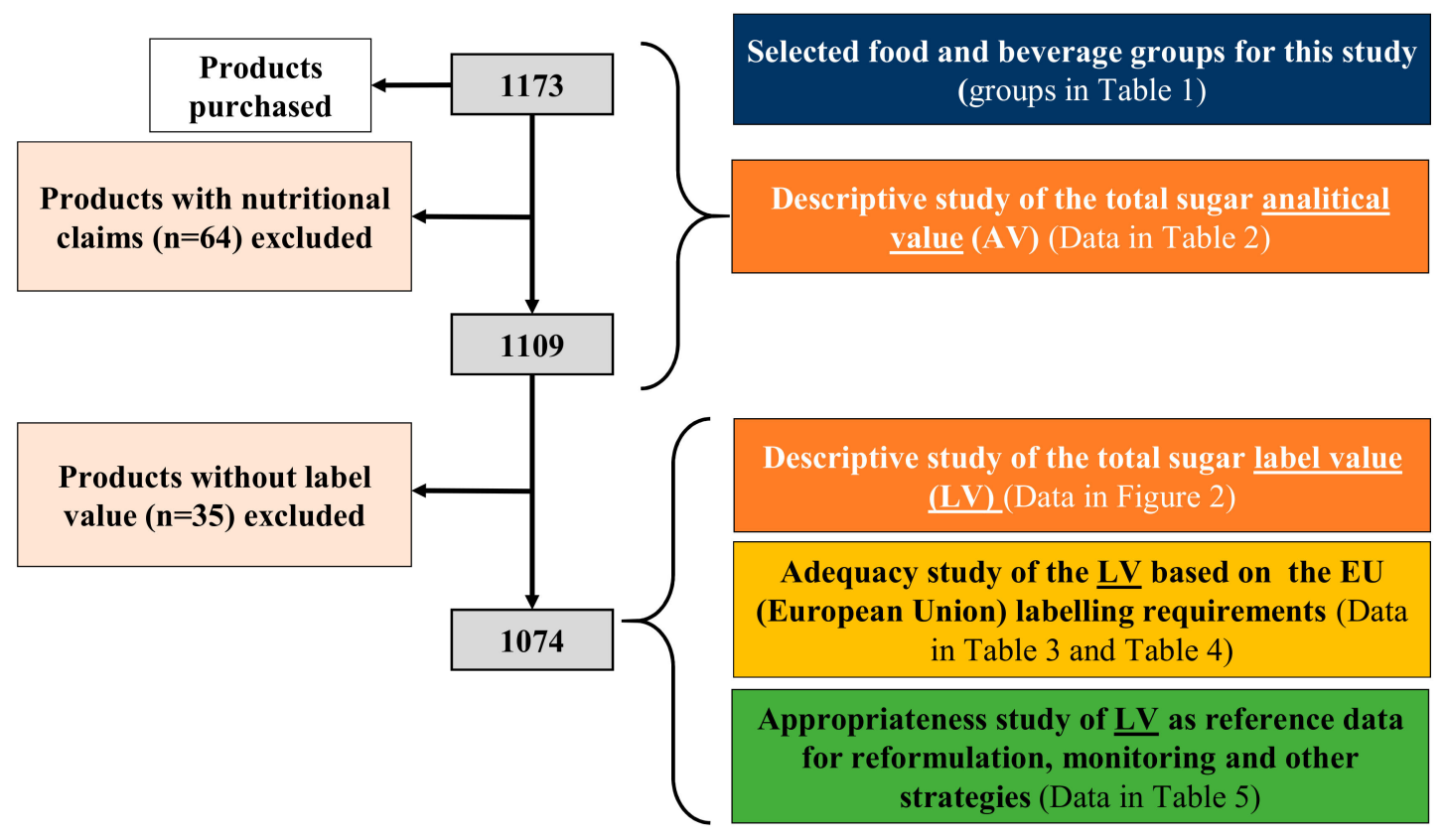

Figure 1. Flow diagram. Sample selection and the different analyses carried out.

\subsection{Descriptive Study of the Total Sugar AV and LV}

Table 2 provides the results of the AV statistical analysis median (25th-75th percentiles, interquartile range) of the total sample analyzed $(n=1173)$. In addition, the analysis of the subsamples according to the presence or absence of a nutrition claim about sugar content showed that the total sugar AV was higher in products without a nutritional claim $(n=1109)$ than in those with such a claim $(n=64)$.

Figure 2 presents the median content of the total sugar LV for each group of products studied in the total sample. The 25th-75th percentiles and interquartile ranges (IQRs) are also shown. 
Table 2. Analytical value (AV) of the total sugar content $(\mathrm{g} / 100 \mathrm{~g}$ of product) in the different groups of products, in the total sample, and in the two subsamples according to the presence or absence of nutritional claims related to sugar content.

\begin{tabular}{|c|c|c|c|c|c|c|c|c|c|}
\hline \multirow[b]{2}{*}{ Groups } & \multicolumn{3}{|c|}{$\begin{array}{l}\text { All Products } \\
(n=1173)\end{array}$} & \multicolumn{3}{|c|}{ Products with Nutritional Claims $(n=64)$} & \multicolumn{3}{|c|}{$\begin{array}{l}\text { Products without Nutritional Claims } \\
\qquad(n=1109)\end{array}$} \\
\hline & $n$ & Median & (P25-P75) IQR & $\mathbf{N}$ & Median & $(\mathrm{P} 25-\mathrm{P} 75) \mathrm{IQR}^{2}$ & $\mathrm{n}$ & Median & (P2-P75) IQR \\
\hline Baking and pastries & 61 & 27.3 & (19.8-31.5) 11.7 & 1 & - & 4.6 & 60 & 27.4 & $(19.9-31.7) 11.9$ \\
\hline Biscuits & 45 & 24.9 & (20.9-34.0) 13.1 & 2 & - & $(0.3,0.6)$ & 43 & 25.3 & $(21.0-34.1) 13.1$ \\
\hline Breakfast cereals and cereal bars & 107 & 25.8 & $(19.3-31.4) 12.1$ & 1 & - & 0.1 & 106 & 25.9 & $(19.3-31.4) 12.1$ \\
\hline Canned pineapple & 10 & 11.7 & $(11.4-12.2) 0.8$ & - & - & - & 10 & 11.7 & (11.4-12.2) 0.8 \\
\hline Cheeses & 30 & 4.4 & (2.8-4.9) 2.1 & - & - & - & 30 & 4.4 & $(2.8-4.9) 2.1$ \\
\hline Chocolate & 92 & 52.0 & (47.3-58.0) 10.7 & 2 & - & $(0.6,13.5)$ & 90 & 52.6 & $(47.8-58.0) 10.2$ \\
\hline Confitures & 30 & 42.5 & (26.3-46.7) 20.4 & 11 & 5.5 & $(2.2-35.0) 32.8$ & 19 & 46.5 & $(42.6-47.0) 4.4$ \\
\hline Crisps & 30 & 0.7 & $(0.4-0.8) 0.4$ & - & - & - & 30 & 0.7 & $(0.4-0.8) 0.4$ \\
\hline Dairy-based desserts & 65 & 15.9 & $(14.1-19.3) 5.2$ & - & - & - & 65 & 15.9 & (14.1-19.3) 5.2 \\
\hline Desserts $^{1}$ & 29 & 23.2 & (12.7-33.8) 21.1 & 4 & 9.8 & $(6.7-23.1) 16.4$ & 25 & 26.7 & $(15.6-39.1) 23.5$ \\
\hline Drinking yoghurt & 10 & 13.1 & $(11.6-13.2) 1.6$ & 2 & - & $(4.0,4.7)$ & 8 & 13.2 & (12.7-13.4) 0.7 \\
\hline Flavoured milk drinks & 20 & 11.3 & $(10.4-12.0) 1.6$ & 2 & - & $(4.6,5.8)$ & 18 & 11.6 & 1.1 \\
\hline Fruit juices & 44 & 10.0 & (9.0-11.0) 2.1 & - & - & - & 44 & 10.0 & (9.0-11.0) 2.1 \\
\hline Ice creams & 45 & 24.2 & $(21.0-27.1) 6.1$ & - & - & - & 45 & 24.2 & $(21.0-27.1) 6.1$ \\
\hline Jam & 5 & 51.2 & $(43.2-58.8) 15.6$ & 1 & - & 2.9 & 4 & 55.0 & $(47.2-59.5) 12.3$ \\
\hline Meat products & 90 & 0.7 & $(0.1-1.2) 1.1$ & - & - & - & 90 & 0.7 & $(0.1-1.2) 1.1$ \\
\hline Milk & 51 & 4.7 & $(4.6-4.8) 0.2$ & - & - & - & 51 & 4.7 & $(4.6-4.8) 0.2$ \\
\hline Nectars & 18 & 9.5 & $(4.3-10.7) 6.4$ & 7 & 4.2 & $(4.1-6.0) 1.9$ & 11 & 10.4 & (9.6-11.1) 1.5 \\
\hline Other Fruits in syrup & 20 & 14.3 & $(13.7-16.4) 2.7$ & 3 & 5.3 & $(5.2-5.8) 0.6$ & 17 & 15.6 & (14.0-16.7) 2.7 \\
\hline Other sweets & 27 & 49.4 & $(0.1-66.9) 66.8$ & 10 & 0.1 & $(0.1-0.1) 0.0$ & 17 & 61.6 & (54.8-67.1) 12.3 \\
\hline Ready meals & 55 & 2.1 & $(1.0-3.2) 2.2$ & - & - & - & 55 & 2.1 & $(1.0-3.2) 2.2$ \\
\hline Sauces & 63 & 6.4 & $(2.4-17.0) 14.6$ & 4 & 3.7 & $(2.5-7.6) 5.1$ & 59 & 6.4 & 16.5 \\
\hline
\end{tabular}


Table 2. Cont.

\begin{tabular}{|c|c|c|c|c|c|c|c|c|c|}
\hline \multirow[b]{2}{*}{ Groups } & \multicolumn{3}{|c|}{$\begin{array}{l}\text { All Products } \\
(n=1173)\end{array}$} & \multicolumn{3}{|c|}{ Products with Nutritional Claims $(n=64)$} & \multicolumn{3}{|c|}{$\begin{array}{l}\text { Products without Nutritional Claims } \\
\qquad(n=1109)\end{array}$} \\
\hline & $n$ & Median & (P25-P75) IQR & $\mathbf{N}$ & Median & $(\mathrm{P} 25-\mathrm{P} 75) \mathrm{IQR}^{2}$ & $\mathbf{n}$ & Median & (P2-P75) IQR \\
\hline Savoury snacks & 45 & 1.2 & $(0.4-2.8) 2.4$ & - & - & - & 45 & 1.2 & $(0.4-2.8) 2.4$ \\
\hline Soy drinks & 5 & 2.1 & $(1.0-2.7) 1.7$ & - & - & - & 5 & 2.1 & $(1.0-2.7) 1.7$ \\
\hline Special packaged bread & 45 & 4.4 & $(3.9-5.1) 1.2$ & - & - & - & 45 & 4.4 & $(3.9-5.1) 1.2$ \\
\hline Sugar Sweetened Beverages & 47 & 7.2 & $(4.7-10.1) 5.4$ & 4 & 4.6 & $(4.0-5.8) 1.9$ & 43 & 7.6 & $(6.0-10.2) 4.2$ \\
\hline Sweets & 34 & 70.2 & (62.8-76.1) 13.3 & 5 & 0.1 & $(0.1-0.1) 0.0$ & 29 & 71.4 & (66.3-81.7) 15.4 \\
\hline Yoghurt & 50 & 12.3 & $(5.8-13.5) 7.7$ & 5 & 4.9 & $(4.9-5.2) 0.3$ & 45 & 12.6 & 3.1 \\
\hline Total & 1173 & 11.6 & $(3.7-26.9) 23.2$ & 64 & 4.2 & $(0.2-5.8) 5.6$ & 1109 & 12.2 & 24.1 \\
\hline
\end{tabular}

Including non-dairy desserts (jello, "tocino de cielo" (pudding made with egg yolks and syrup), and chocolate cake) and powders for dessert preparation (flan powder, cake powder, and chocolate cake powder). ${ }^{2}$ For groups with 1 or 2 items, the median was not calculated, and the data are presented in the IQR column separated by a comma; IQR $=$ Interquartile range. 


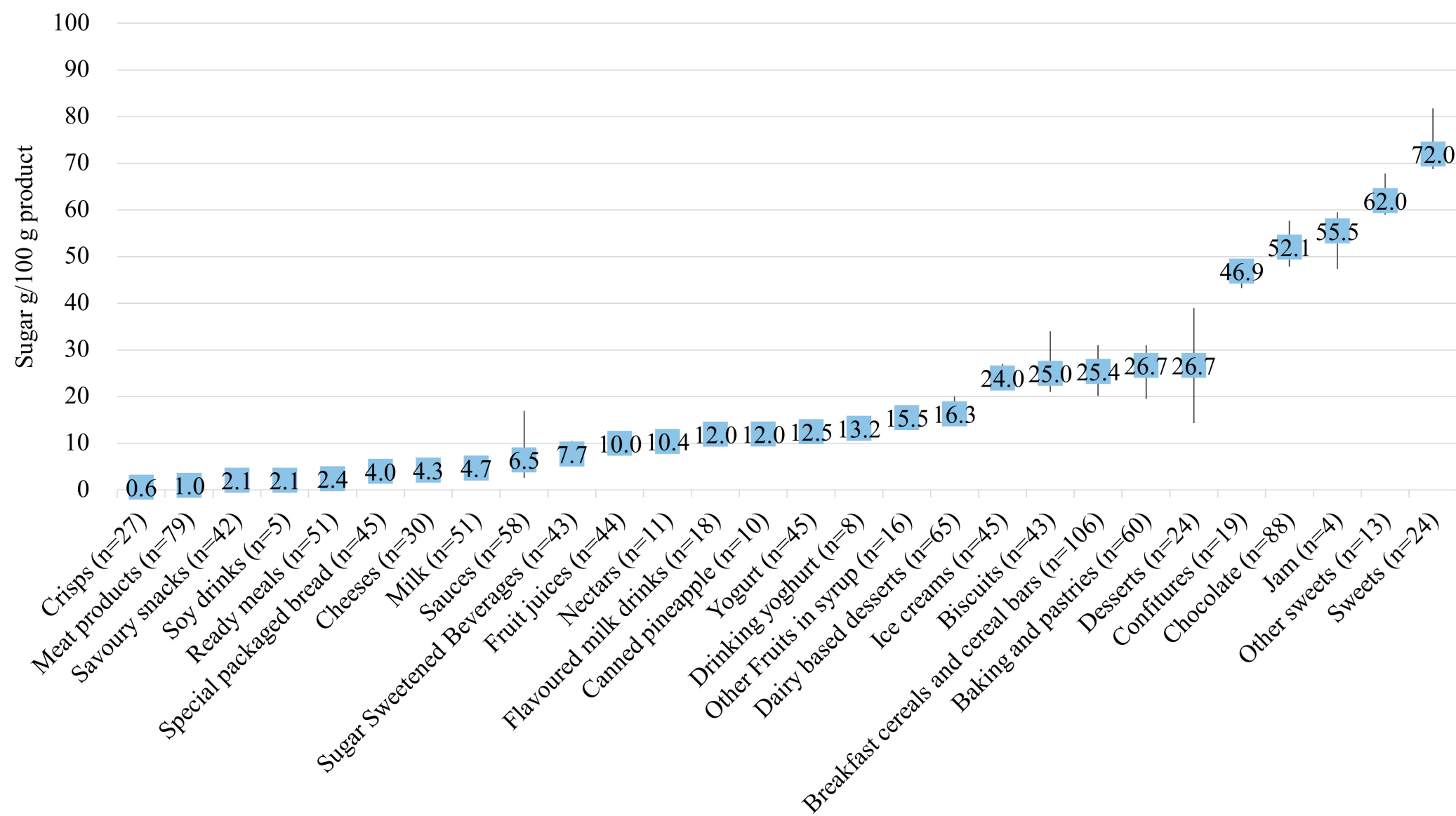

Figure 2. Median and 25th and 75th percentiles of label values (LV) for total sugar for the most consumed groups of products in Spain. 
Moreover, according to data from the AV of products without nutritional claims $(n=1109)$, the food groups were classified as high total sugar content groups $(n=10)$ and no high total sugar content groups $(n=18)$, with the value $22.5 \mathrm{~g} / 100 \mathrm{~g}$ as the cut-off point according to the criterion used for the front of the pack in the UK ( $25 \%$ of the recommended intake in Annex XIII of the EU regulation 1169/2011) [23] and in Chile's Law on Food Labelling and Advertising [24]. There were a total of 10 groups with high total sugar content (in descending order): sweets, other sweets, jam, chocolate, confitures, baking and pastries, desserts, breakfast cereals and cereal bars, biscuits, and ice creams. For the dispersion within each group, the estimated interquartile range was greater than $15 \mathrm{~g} / 100 \mathrm{~g}$ in three groups (desserts, sauces, and sweets), between 15 and $10 \mathrm{~g} / 100 \mathrm{~g}$ in six groups (biscuits, other sweets, jam, breakfast cereals and cereal bars, baking and pastries, and chocolate), and lower than $10 \mathrm{~g} / 100 \mathrm{~g}$ in 19 groups.

\subsection{Adequacy Study of the LV Based on the EU Labelling Requirements for the Tolerance of the Values Declared on the Label}

An adequacy study of the LV compared to the EU labelling requirements was conducted considering the tolerance for the values declared on the label [22]. Tolerance refers to the acceptable difference between the nutritional values declared on the label and those established over the course of official controls in relation to the "nutritional information" or "nutritional labeling" described in Regulation (EU) No. 1169/2011 on the provision of food information provided to consumers [25].

For this study, 64 products with nutritional claims related to sugar content were excluded (Table 2) since their sugar content was reduced to comply with the requirements of Regulation (EC) No. 1924/2006 on the nutritional and health claims made for foods [26], the tolerance requirements for these products are different and are beyond the scope of this study, which focuses instead on products that can be reformulated. In addition, 35 products without LV data ( $0.09 \%$ of the total samples analyzed) were also excluded (11 meat products, five sweets, four ready meals, four from other sweets, three crisps, three savoury snacks, two chocolates, one sauce, one dessert, and one fruit in syrup). Notably, the obligation to show the mandatory nutrition labelling (MNL) (according to Regulation (EU) No. $1169 / 2011$ on the food information provided to the consumer) has been in force since 13 December 2016 [25], but the sampling for this study took place earlier (October 2016). Therefore, the final sample included 1074 products. Therefore, the final sample analyzed was 1074 products.

Of the aforementioned 1074 products, 1057 (98.4\%) met the tolerance ranges, while 17 products did not, among which only five $(0.45 \%$ of the total sample) declared a total sugar LV in the NML that was lower than an AV: one in the "baking and pastries" group ( $n=60 ; 1.7 \%$ of the group's products), one in the "breakfast cereals and cereal bars" group $(n=106 ; 0.9 \%)$, one in the "special packaged bread" group $(n=45 ; 2.2 \%)$, one in the "desserts" group $(n=24 ; 4.2 \%)$, and one in the "dairy-based desserts" group $(n=65 ; 1.5 \%)$, while the remaining $12(1.1 \%$ of the total sample) declared a value in their NML greater than the AV (Table 3$)$.

Table 4 shows the 17 products that did not meet the tolerance ranges. 
Table 3. Products that meet or do not meet the EU tolerance ranges.

\begin{tabular}{|c|c|c|c|c|}
\hline & \multirow[b]{2}{*}{$n$} & \multirow[t]{2}{*}{$\begin{array}{c}\text { Meets } \\
n(\%)\end{array}$} & \multicolumn{2}{|c|}{$\begin{array}{c}\text { Does not Meet } \\
(n(\%))\end{array}$} \\
\hline & & & $\begin{array}{c}\text { Label Value (LV) } \\
\text { >Analytical Vvalue } \\
\text { (AV) }\end{array}$ & $\begin{array}{l}\text { Label value (LV) } \\
\text { <Analytical value } \\
\text { (AV) }\end{array}$ \\
\hline Baking and pastries & 60 & $59(98.3)$ & $0(0)$ & $1(1.7)$ \\
\hline Biscuits & 43 & $43(100)$ & $0(0)$ & $0(0)$ \\
\hline Breakfast cereals and cereal bars & 106 & $102(96.2)$ & $3(2.8)$ & $1(0.9)$ \\
\hline Canned pineapple & 10 & $10(100)$ & $0(0)$ & $0(0)$ \\
\hline Cheese & 30 & $29(96.7)$ & $1(3.3)$ & $0(0)$ \\
\hline Chocolate & 88 & $88(100)$ & $0(0)$ & $0(0)$ \\
\hline Confitures & 19 & $19(100)$ & $0(0)$ & $0(0)$ \\
\hline Crisps & 27 & $27(100)$ & $0(0)$ & $0(0)$ \\
\hline Dairy-based desserts & 65 & $64(98.5)$ & $0(0)$ & $1(1.5)$ \\
\hline Desserts & 24 & $23(95.8)$ & $0(0)$ & $1(4.2)$ \\
\hline Drinking yoghurt & 8 & $8(100)$ & $0(0)$ & $0(0)$ \\
\hline Flavoured milk drinks & 18 & $18(100)$ & $0(0)$ & $0(0)$ \\
\hline Fruit juices & 44 & $44(100)$ & $0(0)$ & $0(0)$ \\
\hline Ice creams & 45 & $45(100)$ & $0(0)$ & $0(0)$ \\
\hline Jam & 4 & $4(100)$ & $0(0)$ & $0(0)$ \\
\hline Meat products & 79 & $78(98.7)$ & $1(1.3)$ & $0(0)$ \\
\hline Milk & 51 & $51(100)$ & $0(0)$ & $0(0)$ \\
\hline Nectars & 11 & $10(90.9)$ & $1(9.1)$ & $0(0)$ \\
\hline Other fruits in syrup & 16 & $16(100)$ & $0(0)$ & $0(0)$ \\
\hline Other sweets & 13 & $13(100)$ & $0(0)$ & $0(0)$ \\
\hline Ready meals & 51 & $51(100)$ & $0(0)$ & $0(0)$ \\
\hline Sauces & 58 & $57(98.3)$ & $1(1.7)$ & $0(0)$ \\
\hline Savoury snacks & 42 & $39(92.9)$ & $3(7.1)$ & $0(0)$ \\
\hline Soy drinks & 5 & $5(100)$ & $0(0)$ & $0(0)$ \\
\hline Special packaged bread & 45 & $44(97.8)$ & $0(0)$ & $1(2.2)$ \\
\hline Sugar Sweetened Beverages & 43 & $41(95.3)$ & $2(4.7)$ & $0(0)$ \\
\hline Sweets & 24 & $24(100)$ & $0(0)$ & $0(0)$ \\
\hline Yoghurt & 45 & 45 (100) & $0(0)$ & $0(0)$ \\
\hline Total & 1074 & 1057 (98.4) & $12(1.1)$ & $5(0.5)$ \\
\hline
\end{tabular}

Table 4. Individual label values (LVs) and analytical values (AVs) of the products that did not meet EU tolerance ranges.

\begin{tabular}{llccc}
\hline \multicolumn{1}{c}{ Groups } & \multicolumn{1}{c}{ Product } & LV (g/100g) & AV (g/100g) & LV-AV (g/100 g) \\
\hline Baking and pastries & Children's industrial bakery & 20 & 38.6 & -18.6 \\
\hline \multirow{3}{*}{$\begin{array}{l}\text { Breakfast cereals and } \\
\text { cereal bars }\end{array}$} & Breakfast cereals with honey & 49 & 35 & 14 \\
\cline { 2 - 5 } & Cereal bars & 36 & 21 & 15 \\
\cline { 2 - 5 } & $\begin{array}{l}\text { Integral breakfast cereals } \\
\text { with fruit }\end{array}$ & 23 & 30.5 & -7.5 \\
\cline { 2 - 5 } & Muesli & 20.2 & 12.9 & 7.3 \\
\hline
\end{tabular}


Table 4. Cont

\begin{tabular}{llccc}
\hline \multicolumn{1}{c}{ Groups } & \multicolumn{1}{c}{ Product } & LV (g/100g) & AV (g/100g) & LV-AV (g/100 g) \\
\hline Cheeses & Spread and melted cheeses & 7 & 4.7 & 2.3 \\
\hline Dairy-based desserts & Custard & 4.5 & 15.2 & -10.7 \\
\hline Desserts & Chocolate cake & 15.2 & 21.9 & -6.7 \\
\hline Meat products & Chopped & 3.5 & 0.8 & 2.7 \\
\cline { 2 - 5 } Nectars & Nectar & 14.4 & 10 & 4.4 \\
\hline Sauces & Mustard & 5.9 & 3.5 & 2.4 \\
\hline \multirow{3}{*}{ Savoury snacks } & Microwave popcorn 1 & 3.8 & 0.4 & 3.4 \\
\cline { 2 - 5 } & Microwave popcorn 2 & 3.8 & 0.8 & 3 \\
\cline { 2 - 5 } & Microwave popcorn 3 & 3.4 & 0.4 & 3 \\
\hline Special packaged bread & Integral tin loaf bread & 3 & 6.2 & -3.2 \\
\hline Sugar Sweetened & Sugar sweetened beverage 1 & 6.3 & 4.1 & 2.2 \\
Beverages & Sugar sweetened beverage 2 & 5.2 & 3.1 & 2.1 \\
\hline
\end{tabular}

3.3. Appropriateness Study of Using the LV as Reference Data for Reformulation, Monitoring, and other Strategies

Table 5 shows the medians and the 25th and 75th percentiles of the LV and AV data obtained for each group and subcategory of products. Of the 28 groups studied, only the "meat products" group presented significant differences between both medians, with the LV being greater than the AV (LV: 1.0 $(0.0-5.0)$ g vs. AV: $0.7(0.1-4.2) \mathrm{g}, p<0.05)$. In addition, in the study by subcategories, within the group of meat products, "cured ham" was the only subcategory that presented significant differences (LV: 0.4 g vs. AV: $0.1 \mathrm{~g}, p<0.05)$.

Table 5. Comparison of the label value (LV) and analytical value (AV) medians of the total sugar for each group and subcategory of products (appropriateness study).

\begin{tabular}{|c|c|c|c|c|}
\hline \multirow[t]{2}{*}{ Groups } & \multirow[t]{2}{*}{ Subcategories } & \multirow[t]{2}{*}{$n$} & $\begin{array}{l}\text { Label Value (LV) } \\
\qquad(\mathrm{g} / \mathbf{1 0 0} \mathrm{g})\end{array}$ & $\begin{array}{l}\text { Analytical Value } \\
\text { (AV) (g/100 g) }\end{array}$ \\
\hline & & & Median (P25-P75) & Median (P25-P75) \\
\hline \multirow{5}{*}{ Baking and pastries } & $\begin{array}{l}\text { Industrial croissants and } \\
\text { similar }\end{array}$ & 11 & $12.0(12.0-13.0)$ & $12.4(12.1-13.0)$ \\
\hline & $\begin{array}{l}\text { Industrial pastries for } \\
\text { children }\end{array}$ & 21 & $32.0(24.6-39.0)$ & $32.0(26.5-38.0)$ \\
\hline & Muffins & 15 & $29.0(26.4-30.0)$ & $29.1(26.9-31.3)$ \\
\hline & Other (donuts, etc.) & 13 & $24.4(19.0-30.0)$ & $24.4(19.8-29.9)$ \\
\hline & Total & 60 & $26.7(19.5-31.0)$ & $27.4(19.9-31.7)$ \\
\hline \multirow{4}{*}{ Biscuits } & Filled biscuits & 18 & $37.0(32.0-41.0)$ & $37.3(33.1-40.7)$ \\
\hline & Sweet biscuit & 21 & $22.0(21.0-24.0)$ & $23.6(20.9-24.6)$ \\
\hline & $\begin{array}{l}\text { Other unfilled biscuits } \\
\text { (digestives, cookies, etc.) }\end{array}$ & 4 & $18.0(17.2-18.0)$ & $18.0(17.2-18.2)$ \\
\hline & Total & 43 & $25.0(21.0-34.0)$ & $25.3(21.0-34.1)$ \\
\hline
\end{tabular}


Table 5. Cont.

\begin{tabular}{|c|c|c|c|c|}
\hline \multirow[t]{2}{*}{ Groups } & \multirow[t]{2}{*}{ Subcategories } & \multirow[t]{2}{*}{$n$} & \multirow{2}{*}{$\begin{array}{c}\begin{array}{c}\text { Label Value (LV) } \\
(\mathrm{g} / 100 \mathrm{~g})\end{array} \\
\text { Median (P25-P75) }\end{array}$} & \multirow{2}{*}{$\begin{array}{c}\text { Analytical Value } \\
(\mathrm{AV})(\mathrm{g} / 100 \mathrm{~g})\end{array}$} \\
\hline & & & & \\
\hline \multirow{9}{*}{$\begin{array}{l}\text { Breakfast cereals and } \\
\text { cereal bars }\end{array}$} & $\begin{array}{l}\text { Breakfast Cereals with } \\
\text { honey }\end{array}$ & 16 & $30.5(26.7-36.0)$ & $31.0(27.5-35.1)$ \\
\hline & Cereal bars & 16 & $30.7(28.0-36.0)$ & $30.4(27.5-34.5)$ \\
\hline & $\begin{array}{l}\text { Chocolate filled Breakfast } \\
\text { Cereals }\end{array}$ & 6 & $33.3(29.0-36.0)$ & $34.3(29.4-36.8)$ \\
\hline & $\begin{array}{l}\text { Chocolate flavoured } \\
\text { Breakfast Cereals }\end{array}$ & 14 & $28.9(28.0-34.0)$ & $29.7(28.7-34.0)$ \\
\hline & Cornflakes cereals & 14 & $7.0(5.0-8.0)$ & $7.1(4.9-8.0)$ \\
\hline & Muesli & 16 & $22.2(20.2-25.7)$ & $22.4(18.9-24.3)$ \\
\hline & Sugared breakfast cereals & 12 & $25.0(24.1-30.5)$ & $24.4(23.4-30.0)$ \\
\hline & Other breakfast cereals & 12 & $19.0(2.8-23.5)$ & $18.8(2.8-23.5)$ \\
\hline & Total & 106 & $25.4(20.2-31.0)$ & $25.9(19.3-31.4)$ \\
\hline Canned pineapple & $\begin{array}{c}\text { Canned pineapple } \\
\text { Total }\end{array}$ & 10 & $12.0(11.6-12.0)$ & $11.7(11.4-12.2)$ \\
\hline Cheeses & $\begin{array}{c}\text { Spread and melted cheeses } \\
\text { Total }\end{array}$ & 30 & $4.3(3.0-5.2)$ & $4.4(2.8-4.9)$ \\
\hline \multirow{8}{*}{ Chocolates } & Chocolate bars & 15 & $49.5(44.0-51.1)$ & $48.9(46.3-51.7)$ \\
\hline & Chocolate eggs and similar & 5 & $57.7(57.6-58.0)$ & $58.0(56.9-58.2)$ \\
\hline & $\begin{array}{l}\text { Chocolate large bars (dark, } \\
\text { with milk, white) }\end{array}$ & 31 & $53.8(46.0-55.9)$ & $54.0(46.3-56.1)$ \\
\hline & $\begin{array}{l}\text { Chocolate like bean (carob) } \\
\text { and similar }\end{array}$ & 5 & $53.8(43.7-64.1)$ & $53.5(44.4-62.4)$ \\
\hline & Chocolate spreads & 5 & $58.0(57.0-59.0)$ & $58.0(56.8-58.1)$ \\
\hline & Chocolates & 20 & $49.6(47.1-51.9)$ & $50.3(46.7-51.8)$ \\
\hline & Cocoa powder & 7 & $70.0(67.0-75.7)$ & $69.9(68.1-75.4)$ \\
\hline & Total & 88 & $52.1(47.9-57.7)$ & $52.0(47.7-58.0)$ \\
\hline Confitures & $\begin{array}{l}\text { Confitures } \\
\text { Total }\end{array}$ & 19 & $46.9(43.2-47.0)$ & $46.5(42.6-47.0)$ \\
\hline Crisps & Crisps & 27 & $0.6(0.5-0.9)$ & $0.7(0.4-0.8)$ \\
\hline \multirow{5}{*}{ Dairy-based desserts } & Custard & 15 & $16.0(15.0-16.8)$ & $15.9(15.0-16.6)$ \\
\hline & Flan & 15 & $20.8(16.0-24.3)$ & $19.7(15.9-23.3)$ \\
\hline & Flavoured fromage frais & 13 & $13.4(13.0-14.0)$ & $13.1(12.3-13.8)$ \\
\hline & $\begin{array}{l}\text { Others (chocolate cups, } \\
\text { mousse, etc.) }\end{array}$ & 22 & $17.4(16.0-20.0)$ & $17.4(15.0-19.9)$ \\
\hline & Total & 65 & $16.3(14.9-20.0)$ & $15.9(14.1-19.3)$ \\
\hline \multirow{3}{*}{ Desserts } & Non-dairy desserts & 16 & $19.6(14.4-35.0)$ & $21.0(14.3-36.0)$ \\
\hline & $\begin{array}{l}\text { Powder for dessert } \\
\text { preparation }{ }^{1}\end{array}$ & 8 & $29.0(13.3-70.4)$ & $28.9(13.6-69.9)$ \\
\hline & Total & 24 & $26.7(14.4-39.0)$ & $26.9(14.3-39.6)$ \\
\hline
\end{tabular}


Table 5. Cont.

\begin{tabular}{|c|c|c|c|c|}
\hline \multirow[t]{2}{*}{ Groups } & \multirow[t]{2}{*}{ Subcategories } & \multirow[t]{2}{*}{$n$} & \multirow{2}{*}{$\begin{array}{c}\begin{array}{c}\text { Label Value (LV) } \\
(\mathrm{g} / 100 \mathrm{~g})\end{array} \\
\text { Median (P25-P75) }\end{array}$} & \multirow{2}{*}{$\begin{array}{c}\text { Analytical Value } \\
\text { (AV) (g/100 g) }\end{array}$} \\
\hline & & & & \\
\hline Drinking yoghurt & $\begin{array}{c}\text { Drinking yoghurt } \\
\text { Total }\end{array}$ & 8 & $13.2(12.7-13.8)$ & $13.2(12.7-13.4)$ \\
\hline Flavoured milk drinks & $\begin{array}{c}\text { Flavoured milk drinks } \\
\text { Total }\end{array}$ & 18 & $12.0(11.0-12.0)$ & $11.6(10.9-12.0)$ \\
\hline Fruit juices & $\begin{array}{l}\text { Fruit juices } \\
\text { Total }\end{array}$ & 44 & $10.0(9.2-11.0)$ & $10.0(9.0-11.0)$ \\
\hline \multirow{3}{*}{ Ice creams } & $\begin{array}{l}\text { Ice cream to share (bars, } \\
\text { frozen cakes, etc.) }\end{array}$ & 25 & $24.0(22.6-26.0)$ & $23.8(21.0-26.2)$ \\
\hline & Individual ice cream & 20 & $25.4(21.5-29.0)$ & $25.0(21.1-28.4)$ \\
\hline & Total & 45 & $24.0(22.0-27.0)$ & $24.2(21.0-27.1)$ \\
\hline Jam & Jam & 4 & $55.5(47.4-59.5)$ & $55.0(47.2-59.5)$ \\
\hline \multirow{8}{*}{ Meat products } & Chopped & 9 & $1.0(0.5-2.5)$ & $0.8(0.1-0.9)$ \\
\hline & Cooked ham & 10 & $1.1(1.0-1.3)$ & $0.9(0.7-1.4)$ \\
\hline & Cured ham & 15 & $0.4(0.1-0.5)$ & $0.1(0.1-0.4)^{*}$ \\
\hline & Cured sausage (chorizo) & 9 & $0.5(0.3-1.0)$ & $0.4(0.1-1.0)$ \\
\hline & $\begin{array}{l}\text { Cured sausage } \\
\text { (salchichon) }\end{array}$ & 9 & $3.0(1.6-3.5)$ & $3.0(1.7-3.8)$ \\
\hline & Sausages & 18 & $1.0(0.5-1.0)$ & $0.7(0.4-1.2)$ \\
\hline & Turkey & 9 & $1.0(0.4-2.0)$ & $0.5(0.1-1.5)$ \\
\hline & Total & 79 & $1.0(0.5-1.6)$ & $0.7(0.1-1.3)^{*}$ \\
\hline \multirow{5}{*}{ Milk } & Whole milk & 15 & $4.6(4.6-4.7)$ & $4.7(4.6-4.8)$ \\
\hline & Semi-skimmed milk & 15 & $4.7(4.7-4.8)$ & $4.7(4.6-4.7)$ \\
\hline & Skimmed milk & 15 & $4.8(4.7-4.8)$ & $4.7(4.7-4.8)$ \\
\hline & Lactose free milk & 6 & $4.8(4.7-4.8)$ & $4.7(4.6-4.8)$ \\
\hline & Total & 51 & $4.7(4.7-4.8)$ & $4.7(4.6-4.8)$ \\
\hline Nectar & Nectar & 11 & $10.4(10.0-11.6)$ & $10.4(9.6-11.1)$ \\
\hline \multirow{4}{*}{ Other fruits in syrup } & Peach & 8 & $16.2(14.0-17.0)$ & $15.9(13.9-17.1)$ \\
\hline & Pineapple & 3 & $15.0(14.0-16.4)$ & $14.2(14.1-16.7)$ \\
\hline & Other fruits & 5 & $14.0(14.0-16.0)$ & $14.3(13.8-15.6)$ \\
\hline & Total & 16 & $15.5(14.0-16.4)$ & $15.0(13.9-16.4)$ \\
\hline Other sweets & $\begin{array}{r}\text { Other sweets }^{2} \\
\text { Total }\end{array}$ & 13 & $62.0(59.0-67.8)$ & $62.0(59.3-67.5)$ \\
\hline \multirow{4}{*}{ Ready meals } & Lasagna /cannelloni & 11 & $2.7(1.2-3.4)$ & $2.7(1.0-3.4)$ \\
\hline & Pizza & 20 & $2.4(1.7-3.5)$ & $2.7(1.7-3.4)$ \\
\hline & Others & 20 & $2.0(1.0-3.0)$ & $1.9(0.8-2.8)$ \\
\hline & Total & 51 & $2.4(1.2-3.1)$ & $2.3(1.3-3.3)$ \\
\hline
\end{tabular}


Table 5. Cont

\begin{tabular}{|c|c|c|c|c|}
\hline \multirow[t]{2}{*}{ Groups } & \multirow[t]{2}{*}{ Subcategories } & \multirow[t]{2}{*}{$n$} & \multirow{2}{*}{$\begin{array}{c}\begin{array}{c}\text { Label Value (LV) } \\
\text { (g/100 g) }\end{array} \\
\text { Median (P25-P75) }\end{array}$} & \multirow{2}{*}{$\begin{array}{c}\text { Analytical Value } \\
\text { (AV) (g/100 g) }\end{array}$} \\
\hline & & & & \\
\hline \multirow{5}{*}{ Sauces } & Ketchup & 14 & $21.4(19.3-22.8)$ & $20.8(19.1-22.8)$ \\
\hline & Mayonnaise & 14 & $1.6(1.4-3.0)$ & $1.4(1.0-1.9)$ \\
\hline & Tomato sauce & 13 & $7.4(6.7-8.1)$ & $7.2(7.1-7.8)$ \\
\hline & Other sauces & 17 & $3.0(2.6-5.9)$ & $3.2(2.6-4.9)$ \\
\hline & Total & 58 & $6.5(2.6-17.0)$ & $6.4(2.4-17.0)$ \\
\hline \multirow{4}{*}{ Savoury snacks } & Corn snacks & 15 & $2.2(1.0-4.1)$ & $2.1(0.8-4.2)$ \\
\hline & Microwave popcorn & 8 & $1.1(0.4-3.6)$ & $0.4(0.4-0.9)$ \\
\hline & Other savoury snacks ${ }^{3}$ & 19 & $1.8(0.7-5.1)$ & $1.9(0.1-4.9)$ \\
\hline & Total & 42 & $2.1(0.8-3.8)$ & $1.4(0.4-3.7)$ \\
\hline Soy drinks & $\begin{array}{l}\text { Soy drinks } \\
\text { Total }\end{array}$ & 5 & $2.1(0.7-2.8)$ & $2.1(1.0-2.7)$ \\
\hline \multirow{4}{*}{ Special packaged bread } & White tin loaf bread & 14 & $3.2(2.9-4.0)$ & $4.0(3.5-4.5)$ \\
\hline & Integral tin loaf bread & 16 & $3.0(2.7-4.2)$ & $4.2(3.4-4.8)$ \\
\hline & Toasted bread & 15 & $5.1(4.3-5.6)$ & $5.5(4.4-5.9)$ \\
\hline & Total & 45 & $4.0(3.0-5.0)$ & $4.4(3.9-5.1)$ \\
\hline \multirow{3}{*}{$\begin{array}{l}\text { Sugar sweetened } \\
\text { beverages }\end{array}$} & Beverages with fruits & 3 & $11.0(4.6-11.9)$ & $10.8(4.6-11.9)$ \\
\hline & $\begin{array}{l}\text { Sugar Sweetened } \\
\text { beverages }\end{array}$ & 40 & $7.5(6.3-10.2)$ & $7.5(6.1-10.1)$ \\
\hline & Total & 43 & $7.7(6.3-10.5)$ & $7.6(6.0-10.2)$ \\
\hline Sweets & Sweets & 24 & $72.0(68.8-81.8)$ & $71.9(67.2-81.9)$ \\
\hline \multirow{5}{*}{ Yoghurt } & Plain yoghurt & 9 & $4.0(4.0-4.3)$ & $4.0(3.9-4.8)$ \\
\hline & Flavoured yoghurt & 18 & $12.8(11.0-14.0)$ & $12.8(11.4-13.5)$ \\
\hline & Fruit Yoghurt & 12 & $14.1(12.8-15.0)$ & $14.3(12.8-15.1)$ \\
\hline & Sugar sweetened yoghurt & 6 & $12.5(12.3-13.3)$ & $12.4(12.2-13.4)$ \\
\hline & Total & 45 & $12.5(10.1-14.0)$ & $12.6(10.5-13.6)$ \\
\hline
\end{tabular}

* Significant differences between the labelling value (LV) and laboratory analysis value (AV) (median test for unpaired samples); ${ }^{1}$ Powder for dessert preparation (flan powder, cake powder, chocolate cake powder, etc.);

${ }^{2}$ Sweet gels, liquorice, marshmallow, chewing gum; ${ }^{3}$ Wheat rinds, pork rinds, potato sticks, crackers.

\section{Discussion}

To study the content of total sugar, we presented the AVs of 28 groups of processed food products that are most frequently consumed by the Spanish population. The groups whose reformulation could have the greatest impact on public health were identified by their high sugar content and dispersion, which indicates that there is room for the reduction of their sugar content and that reformulation is, therefore, possible.

The most commonly consumed groups, especially by children and adolescents, should also be distinguished and prioritized (compared to those consumed more rarely) based on their energy contribution to the diet (cereals and meats and derivatives, among others), added sugar contribution to the diet (sugar sweetened beverages, chocolate, and nectars), or both (dairy products, baking and pastries, and breakfast cereals, among others) $[16,27,28]$. In Europe, high sugar consumption, especially in children and adolescents [29], has become a major public health concern, which is highlighted by 
scientific reports and studies associating high sugar consumption with an increased risk of dental caries [30], overweight [31], cardiometabolic risk factors [32], and adult cardiovascular mortality [33].

This study, promoted by the Observatory of Nutrition and Study of Obesity of AESAN in the framework of the NAOS Strategy, answers the call to action of the EU from the Council Conclusions of June 2016 for the improvement of food to develop a national reformulation initiative (the "Collaboration Plan for the improvement of the composition of food and beverages and other measures 2020" [34]), which is in line with the EU Plan of Action against Childhood Obesity 2014-2020 [35] and the WHO European Action Plan for Food and Nutrition 2015-2020 [36].

One of the limitations of this study is its small sample size, which was mainly due to our limited budget. For some subcategories, this reduced sample size was due to other specific reasons. For "pineapple in syrup", the market is dominated by a single brand, and for "beverages with fruits" (included in the group "sugar sweetened beverages"), we decided to create a new subcategory, resulting in only three products; sugar content in fruit is very different from that in the rest of the group, so the groups could not all be considered together. For this reason (sample size) and to prevent the influence of the most distal values, the median was used as a measure of the central tendency. Moreover, to produce a snapshot of sugar availability in our food environment and to estimate the potential impact of reformulation, market shares should have been considered. In our more feasible approach, the products in each subcategory were selected according to the results of a food market study that identified the most commonly consumed food products.

Our results provide novel information on the presence of total sugars in our food environment. This study quantifies the total sugar content in the main groups of processed products on the Spanish market, assesses the adequacy of label values based on the tolerance ranges for sugar according to EU labelling requirements, and assesses the appropriateness of using the LV as reference data. These are relevant aspects for designing and implementing actions aimed at reducing sugar consumption, which will help tackle obesity and its consequences for health.

Reformulation policies aimed at reducing the content of certain nutrients are some of the measures recommended by international institutions and organizations (European Union, WHO, OECD) to improve the quality of diets, reduce the consumption of foods high in salt, fats, and sugars, and prevent obesity and its related non-communicable diseases [37].

The Annex II on added sugars [8] proposes that the Member States should set a general benchmark for a minimum of $10 \%$ added sugar reduction in food products against their baseline levels or to move towards a 'best in class' level of sugar content.

In Spain, in order to establish the sugar reduction objectives of the "Collaboration plan for the improvement of the composition of food and beverages and other measures 2020" [34], AESAN opted in 2017 to deploy the first strategy mentioned in Annex II, which entails the reduction of a percentage of sugar from the basal median content, which was considered a viable and realistic method. Thus, all companies in the sector related to each food subcategory made a commitment to follow this plan. The evaluation of this plan, after its completion in 2020, will allow us to determine the degree of compliance with the objectives and to draw pertinent conclusions about the contribution of this initiative and its possible "drag effect" on other subsequent initiatives.

This work shows that most of the analyzed processed products (98.4\%) meet the European Union tolerances for nutrient values declared on the labels. A very low percentage of products in our study did not meet the tolerance values because they had a lower LV than AV $(0.45 \%)$. A study conducted with a sample of products that contribute the most to sodium intake in the United States [38] concluded that the majority of the labeling and analytical values agree with each other; thus, label under-declaration is limited. However, the authors observed that the differences in total sugars were greater and more systematic and that $19 \%$ products did not meet tolerance requirements because their labelled total sugars were lower than their analytical data. In our study, each of the five products that did not meet tolerance levels (due to a lower LV than $\mathrm{AV}$ ) belonged to a different group (baking and pastries, 
breakfast cereals, special packaged bread, desserts, and dairy-based desserts), which also included a considerable number of other products that did meet the tolerance requirements.

To our best knowledge, this is the first time that the LVs and AVs of the studied processed products groups were compared in Spain, showing that the total sugar values are similar under both methods for most of the products and subcategories, according to the tolerance requirements for the nutritional information established by the European Union. Of the 28 food and beverage groups and the 77 subcategories analyzed, only the "meat products" group and, specifically, the "cured ham" subcategory, showed significant differences between their median AV and LV data. Taking into account the low sugar content of cured ham and the specific characteristics of its manufacturing and maturation process, such as the infiltration variability of additives depending on the part of the product (fat, bone, etc.), these differences are not considered relevant.

In light of these findings, we conclude first that a reduction in sugar content is feasible in a wide range of products. We recommend setting benchmarks at the subcategory level because this level includes similar products to which the same quality standards apply and allows one to compare the nutrient content of each product within a subcategory to its median, thus facilitating the identification of products with the greatest potential for reformulation.

Moreover, our results show a remarkably high compliance with the tolerance requirements and the appropriateness of the declared total sugar content in the MNL for most sold packaged processed products in Spain.

Thus, the MNL provides an accessible and efficient tool for various aims: to inform consumers truthfully, to conduct studies on the sugar content or other nutrients in labeled products, to establish and monitor reformulation initiatives, to implement front-of-pack initiatives, to apply nutritional profiles for different objectives, and for food advertising policies, among others. Regulation (EU) No. 1169/2011 [25] establishes (starting from 13 December 2016) the mandatory obligation to provide a nutritional declaration on the labels of most processed food products. This declaration must include the energy values and six nutrients, one of them being the sugar content.

Briefly, the groups identified to boost reformulation policies based on their sugar content, the differences in sugar content between similar products, and their contributions to energy, added sugars, or both to the diet are the following: sweets, other sweets, jam, chocolate, confitures, desserts, baking and pastries, breakfast cereals and cereals bars, biscuits, ice cream, sauces, meat products, sugar sweetened beverages, nectars, and dairy products $[16,27,28]$.

The results obtained from this research may help make the nutritional composition of food products more visible, to better explore the feasibility of improving nutrition and evaluate related actions.

\section{Conclusions}

The results of the present study will help identify the groups of food products whose sugar content reduction could have the greatest impact on public health. In addition, we showed the adequacy of labelling values with the EU labelling tolerance requirements; labelling values are, therefore, an adequate tool to implement and evaluate actions aimed at reducing sugar consumption.

Author Contributions: Conceptualization and methodology, M.J.Y.-B., L.M.B., A.M.L.-S., R.M.O., M.Á.D.-R.S., and SUCOPROFS; formal analysis, M.J.Y.-B., L.M.B., M.G.-S., and A.M.L.-S.; original draft preparation, M.J.Y.-B., L.M.B., M.G.-S., and A.M.L.-S.; writing-review and editing, M.J.Y.-B., L.M.B., A.M.L.-S., M.G.-S., R.M.O., M.G.-P., M.Á.D.-R.S., and SUCOPROFS; funding acquisition and contract design, M.J.Y.-B., M.Á.D.-R.S., and SUCOPROFS. All authors have read and agreed to the published version of the manuscript.

Funding: This research received funding from the Spanish Food Safety and Nutrition Agency.

Acknowledgments: Technical support was provided by Estefania Labrado Mendo. Sample collection and analytics were done by the AENOR Laboratory. SUCOPROFS (Sugar content in processed foods in Spain) Study researchers. AGENCIA ESPAÑOLA DE SEGURIDAD ALIMENTARIA Y NUTRICIÓN. VOCALÍA ASESORA PARA LA ESTRATEGIA NAOS: Napoleón Pérez Farinós, Sara Santos Sanz, Carmen Villar Villalba, Ma Araceli García López, Teresa Robledo de Dios. UNIVERSIDAD COMPLUTENSE DE MADRID. FACULTAD DE 
FARMACIA. DEPARTAMENTO DE NUTRICIÓN Y CIENCIA DE LOS ALIMENTOS: Esther Cuadrado Soto, Aránzazu Aparicio Vizuete.

Conflicts of Interest: The authors declare no conflict of interest.

\section{References}

1. Blundell, J.E.; Baker, J.L.; Boyland, E.; Blaak, E.; Charzewska, J.; de Henauw, S.; Frühbeck, G.; Gonzalez-Gross, M.; Hebebrand, J.; Holm, L.; et al. Variations in the prevalence of obesity among european countries, and a consideration of possible causes. Obes. Facts 2017, 10, 25-37. [CrossRef] [PubMed]

2. Health Effects of Dietary Risks in 195 Countries, 1990-2017: A Systematic Analysis for the Global Burden of Disease Study 2017-The Lancet. Available online: https://www.thelancet.com/article/S0140-6736(19)300418/fulltext (accessed on 21 January 2020).

3. High Level Panel of Experts (HLPE). Nutrition and Food Systems. A Report by the High Level Panel of Experts on Food Security and Nutrition of the Committee on World Food Security; Committee on World Food Security: Rome, Italy, 2017.

4. White Paper on a Strategy for Europe on Nutrition, Overweight and Obesity Related to Health Issues; COM(2007) 279 Final; Commission of the European Communities: Brussels, Belgium, 2007.

5. EU Framework for National Salt Initiatives. 2008. Available online: https://ec.europa.eu/health/ph_ determinants/life_style/nutrition/documents/salt_initiative.pdf (accessed on 14 February 2020).

6. EU Framework for National Initiatives on Selected Nutrients. 2009. Available online: https://ec.europa.eu/ health/sites/health/files/nutrition_physical_activity/docs/euframework_national_nutrients_en.pdf (accessed on 14 February 2020).

7. Annex I Saturated Fats. EU Framework for National Initiatives on Selected Nutrients. 2012. Available online: https://ec.europa.eu/health/sites/health/files/nutrition_physical_activity/docs/satured_fat_eufnisn_ en.pdf (accessed on 14 February 2020).

8. Annex II Added Sugars. EU Framework for National Initiatives on Selected Nutrients. 2015. Available online: https://ec.europa.eu/health/sites/health/files/nutrition_physical_activity/docs/added_sugars_en.pdf (accessed on 14 February 2020).

9. Ortega, R.M.; López-Sobaler, A.M.; Ballesteros, J.M.; Pérez-Farinós, N.; Rodríguez-Rodríguez, E.; Aparicio, A.; Perea, J.M.; Andrés, P. Estimation of salt intake by $24 \mathrm{~h}$ urinary sodium excretion in a representative sample of Spanish adults. Br. J. Nutr. 2011, 105, 787-794. [CrossRef] [PubMed]

10. Pérez-Farinós, N.; Dal Re Saavedra, M.Á.; Villar Villalba, C.; Robledo de Dios, T. Trans-fatty acid content of food products in Spain in 2015. Gac. Sanit. 2016, 30, 379-382. [CrossRef] [PubMed]

11. Contenido de sal en los Alimentos en España. 2012. Agencia Española de Consumo, Seguridad Alimentaria y Nutrición; Ministerio de Sanidad, Servicios Sociales e Igualdad. Madrid; 2015. Available online: http://www.aecosan.msssi.gob.es/AECOSAN/docs/documentos/nutricion/estudio_contenido_sal_ alimentos.pdf (accessed on 22 January 2020).

12. Trans Fatty Acid Content in Foods in Spain 2010. Spanish Agency for Consumer Affairs, Food Safety and Nutrition; Ministry of Health, Social Services and Equality. Madrid; 2014. Available online: http://www.aecosan.msssi.gob.es/AECOSAN/docs/documentos/nutricion/Informe_ingles_Contenido_ AGT_alimentos_2010_ingles.pdf (accessed on 22 January 2020). 
13. Trans Fatty Acid Content in Food in Spain 2015. Spanish Agency for Consumer Affairs, Food Safety and Nutrition; Ministry of Health, Social Services and Equality. Madrid; 2016. Available online: http://www. aecosan.msssi.gob.es/AECOSAN/docs/documentos/nutricion/Informe_AGT2015_Ingles.pdf (accessed on 22 January 2020).

14. Reformulacion de Alimentos. Convenios y Acuerdos; Aecosan-Agencia Española de Consumo, Seguridad Alimentaria y Nutrición. Available online: http://www.aecosan.msssi.gob.es/AECOSAN/web/nutricion/ ampliacion/reformulacion_alimentos.htm (accessed on 22 January 2020).

15. Pérez Farinós, N.; Santos Sanz, S.; Dal Re, M.Á.; Yusta Boyo, J.; Robledo, T.; Castrodeza, J.J.; Campos Amado, J.; Villar, C. Salt content in bread in Spain, 2014. Nutr. Hosp. 2018, 35, 650-654. [CrossRef] [PubMed]

16. Estudio ENALIA 2012-2014: Encuesta Nacional de Consumo de Alimentos en Población Infantil y Adolescente. Agencia Española de Consumo, Seguridad Alimentaria y Nutrición; Ministerio de Sanidad, Servicios Sociales e Igualdad. Madrid; 2017. Available online: http://www.aecosan.msssi.gob.es/AECOSAN/ docs/documentos/seguridad_alimentaria/gestion_riesgos/Informe_ENALIA2014_FINAL.pdf (accessed on 22 January 2020).

17. García, M. Informe 2015 del Mercado de Supermercados-Informes y Reportajes de Alimentación en Alimarket, Información Económica Sectorial. Available online: http://www.alimarket.es/alimentacion/ informe/182798/informe-2015-del-mercado-de-supermercados (accessed on 22 January 2020).

18. Orden de 18 de Julio de 1989 por la que se Aprueban los Métodos Oficiales de Análisis para el Control de Determinados Azúcares Destinados al Consumo Humano. Available online: https://www.boe.es/buscar/doc. php?id=BOE-A-1989-17511 (accessed on 22 January 2020).

19. Laying Down Community Methods of Analysis for Testing Certain Sugars Intended for Human Consumption; The Commission of the European Communities: Brussels, Belgium, 1979; 79/78 6/EEC.

20. Joint Action on Nutrition and Physical Activity (JANPA). Work Package 5 Nutritional Information Monitoring and Food Reformulation Prompting; European Commission 3rd Health Programme (2014-2020): Brussels, Belgium, 2014.

21. Menard, C.; Dumas, C.; Goglia, R.; Spiteri, M.; Gillot, N.; Combris, P.; Ireland, J.; Soler, L.G.; Volatier, J.L. OQALI: A French database on processed foods. J. Food Compos. Anal. 2011, 24, 744-749. [CrossRef]

22. Guidance Document for Competent Authorities for the Control of Compliance with EU Legislation with Regard to the Setting of Tolerances for Nutrients Values Decslred on a Label; European Commission: Brussels, Belgium, 2012.

23. Guide to Creating a Front of Pack (FoP) Nutrition Label for Pre-Packed Products Sold through Retail Outlets; Department of Health and Food Standard Agency: London, UK, 2016.

24. Aprobación de Nueva ley de Alimentos en Chile: Resumen del Proceso. Organización de las Naciones Unidas para la Alimentación y la Agricultura Organización Panamericana de la Salud Santiago. 2017. Available online: http://www.dinta.cl/wp-content/uploads/2018/11/FAO-Ley-etiquetado-Chile-Resumen-2017.pdf (accessed on 22 January 2020).

25. EUR-Lex-32011R1169-EN-EUR-Lex. Available online: https://eur-lex.europa.eu/legal-content/EN/ALL/ ?uri=CELEX\%3A32011R1169 (accessed on 22 January 2020).

26. EUR-Lex-32006R1924-EN_EUR-Lex. Available online: https://eur-lex.europa.eu/legal-content/en/ALL/ ?uri=CELEX\%3A32006R1924 (accessed on 22 January 2020).

27. Ruiz, E.; Ávila, J.M.; Valero, T.; del Pozo, S.; Rodriguez, P.; Aranceta-Bartrina, J.; Gil, Á.; González-Gross, M.; Ortega, R.M.; Serra-Majem, L.; et al. Energy intake, profile, and dietary sources in the spanish population: Findings of the anibes study. Nutrients 2015, 7, 4739-4762. [CrossRef] [PubMed]

28. Ruiz, E.; Rodriguez, P.; Valero, T.; Ávila, J.M.; Aranceta-Bartrina, J.; Gil, Á.; González-Gross, M.; Ortega, R.M.; Serra-Majem, L.; Varela-Moreiras, G. Dietary intake of individual (free and intrinsic) sugars and food sources in the spanish population: Findings from the ANIBES study. Nutrients 2017, 9, 275. [CrossRef] [PubMed]

29. Azaïs-Braesco, V.; Sluik, D.; Maillot, M.; Kok, F.; Moreno, L.A. A review of total \& added sugar intakes and dietary sources in Europe. Nutr. J. 2017, 16, 6. [PubMed]

30. Moynihan, P. Sugars and dental caries: evidence for setting a recommended threshold for intake. Adv. Nutr. 2016, 7, 149-156. [CrossRef] [PubMed]

31. Te Morenga, L.; Mallard, S.; Mann, J. Dietary sugars and body weight: Systematic review and meta-analyses of randomised controlled trials and cohort studies. BMJ 2012, 346, e7492. [CrossRef] [PubMed] 
32. Te Morenga, L.A.; Howatson, A.J.; Jones, R.M.; Mann, J. Dietary sugars and cardiometabolic risk: Systematic review and meta-analyses of randomized controlled trials of the effects on blood pressure and lipids. Am. J. Clin. Nutr. 2014, 100, 65-79. [CrossRef] [PubMed]

33. Yang, Q.; Zhang, Z.; Gregg, E.W.; Flanders, W.D.; Merritt, R.; Hu, F.B. Added sugar intake and cardiovascular diseases mortality among US adults. JAMA Intern. Med. 2014, 174, 516-524. [CrossRef] [PubMed]

34. Collaboration PLAN for the Improvement of the Composition of Food and Beverages and Other Measures 2020. Spanish Agency for Consumer Affairs, Food Safety and Nutrition; Ministry of Health, Social Services and Equality. Madrid; 2018. Available online: http://www.aecosan.msssi.gob.es/AECOSAN/docs/ documentos/nutricion/Plan_Colaboracion_INGLES.pdf (accessed on 22 January 2020).

35. EU Action Plan on Childhood Obesity 2014-2020. Available online: https://ec.europa.eu/health/sites/ health/files/nutrition_physical_activity/docs/childhoodobesity_actionplan_2014_2020_en.pdf (accessed on 14 February 2020).

36. European Food and Nutrition Action Plan 2015-2020. World Health OrganizationRegional Office for Europe. Available online: http://www.euro.who.int/_data/assets/pdf_file/0003/294474/European-Food-NutritionAction-Plan-20152020-en.pdf?ua=1 (accessed on 22 January 2020).

37. Federici, C.; Detzel, P.; Petracca, F.; Dainelli, L.; Fattore, G. The impact of food reformulation on nutrient intakes and health, a systematic review of modelling studies. BMC Nutr. 2019, 5, 2. [CrossRef] [PubMed]

38. Ahuja, J.K.C.; Li, Y.; Nickle, M.S.; Haytowitz, D.B.; Roseland, J.; Nguyen, Q.; Khan, M.; Wu, X.; Somanchi, M.; Williams, J.; et al. Comparison of label and laboratory sodium values in popular sodium-contributing foods in the United States. J. Acad. Nutr. Diet. 2019, 119, 293-300. [CrossRef] [PubMed]

(C) 2020 by the authors. Licensee MDPI, Basel, Switzerland. This article is an open access article distributed under the terms and conditions of the Creative Commons Attribution (CC BY) license (http://creativecommons.org/licenses/by/4.0/). 